\title{
WHY AND HOW ARE CAVES “ORGANIZED": DOES THE PAST OFFER A KEY TO THE PRESENT
}

\section{ZAKAJ IN KAKO SO KRAŠKE VOTLINE “ORGANIZIRNE”: ALI PRETEKLOST NUDI KJUČ K SEDANJOSTI?}

DAVID J. LOWE ${ }^{1}$

${ }^{1}$ Limestone Research Group, University of Huddersfield, Queensgate, Huddersfield, HD1 3DH, UK. 
UDK: 551.44(410)

\section{David J. Lowe: Zakaj in kako so kraške votline “organizirne”: Ali preteklost nudi kjuč k sedanjosti?}

Prenekatere jame v karbonatnih sekvencah (in morda tudi drugod) izkazujejo opazno prostorsko organizacijo, pri čemer je poudarjeno kopičenje rovov v prostoru (drugega nad drugim). Mnoge starejše razlage tega zgoščevanja vključujejo "recentno" dogajanje in medsebojne vplive. Nove ideje, ki temeljijo na proučevanju "denudiranih" ali "brezstropih" jam, pripisujejo velik pomen pojavom in odnosom, ki so sicer znani že dolgo, a so jih raziskovalci puščali ob strani kot "neznačilne", "nepomembne" ali celo "nemogoče", ob enem pa jih interpretirajo na novo. Tako je potrebno nekatere uveljavljene razlage trodimenzionalnega kopičenja rovov popolnoma prevetriti. Opazovanja ne podpirajo privzetka, da vsaka stratigrafska (lezika) ali tektonska (razpoka) nezveznost že sama po sebi odpira vodi pot in in je zato samodejno žarišče nastajanja kraških kanalov. V svojem prvotnem, "pred-jamskem" stanju - ko so posamezne votline v kamnini zgolj možne - karbonatne gmote niso nujno hidrološko aktivne, niti niso geološko homogene. Nova opazovanja in prevrednotenje starejšega znanja nakazujejo, da se "začetje" bodočih rovov odvije samo na majhni podmnožici vseh lezik, ki so priviligirane že v začetku in že od kraja odrejajo smernice bodočemu razvoju kanalov. Spoznanje te temeljne vloge kaže možno pot k razumevanju organizacije jamskih sistemov in kliče po podaljšanju spelogenetske časovne lestvice prav $\mathrm{v}$ čas diageneze.

Ključne besede: speleogeneza, začetje, brezstrope jame, Yorkshire, Forest of Dean.

\section{Abstract}

UDC: $551.44(410)$

\section{David J. Lowe: Why and how are caves "organized": does the past offer a key to the present}

Many caves within carbonate (and perhaps other) rock sequences display marked spatial organization, particularly a tendency to group within vertical clusters. Most past explanations of clustering involve "recent" effects and interactions. New ideas, based on study of "denuded" or "unroofed" caves, acknowledge but reinterpret features and relationships that were observed long ago and commonly dismissed as "atypical", "irrelevant" or "impossible". Some traditional explanations of vertical clustering must now be re-assessed. Assumptions that any stratigraphical (bedding plane) or joint/fault fissure in carbonate rock provides (or provided) a de facto route for fluid transfer, and hence a focus for void development, are not confirmed by observation. Primitive pre-cave, but potentially cavernous, carbonate masses are not inevitably active hydrologically; nor are they geologically homogeneous. New evidence, and re-evaluation of earlier observations, implies that dissolutional void "inception" is related to a minor subset of all stratigraphical partings, which dominate initially, imprinting incipient guidance for later cave development. Recognition of this fundamental role provides a possible key to understanding the organization of cave systems and necessitates acceptance of an expansion of speleogenetic timescales back to the time of diagenesis.

Key words: speleogenesis, inception, unroofred caves, Yorkshire, Forest of Dean. 


\section{INTRODUCTION}

More than 150 years ago the British geologist Sir Charles Lyell introduced the idea that "The Present is the Key to the Past". By this he meant that observation and understanding of geological processes taking place today could provide clues to essentially similar processes that operated in the past, to give rise to the presently visible rocks and structural features. Over the years Lyell's sweeping statement has been demonstrated to be true in many situations and, to a possibly large degree, it remains valid. Reciprocally, however, information provided by ancient rocks and structures can provide valuable clues that, potentially, can help us to predict current geological relationships. This possibility is as valid for questions of cave and karst development as it is in other branches of the earth sciences.

\section{BRIEF HISTORICAL COMMENTS}

Many workers in cave and karst science have described one form or another of vertical clustering or segregation of cave passages. As discussed recently by workers such as Mihevc (1998) and Šušteršič (1998), this situation is as obvious in unroofed caves as it is in active or recently abandoned underground situations. Some past workers have considered vertical clustering to be related to relict landscape features described as "erosion surfaces" or "erosion levels". Others have found difficulty in accepting such concepts, and instead they have related vertical clusters of cave passages to various aspects of "geological control" or, perhaps more correctly, "geological guidance". However, whereas geological guidance is relatively easy to appreciate in undeformed, sub-horizontal successions, its role has been less successfully deduced and described in heavily fractured and highly folded terrains.

White (1988, p.85), noted that: “...one of the tasks of cave origin models is to explain why cave tiers sometimes form...". In context the word "sometimes" is important, as cave tiers appear not to be ubiquitous in all rock sequences and structural situations. This in itself is significant, as cave tiers would be expected as the norm if surface erosion levels (non-karstic features), and watertables related to them, were the dominant factors affecting their establishment.

During the history of cave research many cave development theories have appeared. Some were accepted with or without subsequent improvement, others reverted to obscurity. Some seemed to provide an explanation of cave tiers, at least locally. For instance, discussing an earlier paper by Sweeting, the English geomorphologist Warwick (1953) reported: "Miss Sweeting (1950) has shown that some of the large chambers (caverns) of North-west Yorkshire occur at well-defined levels, which are probably connected with the successive deepening of the Dales.". Of course, there had also been an awareness of cave tiers before 1950, and various workers have discussed their origins and relevance since then. This paper does not set out to examine early ideas in detail, merely to record a number of them in passing.

An early reference was by Sawicki (1909), who referred to "evolution levels", said to relate to a succession of piezometric surfaces. Some of Sawicki's ideas appear to be in close agreement with aspects of more recent cave development theories. In 1957 Droppa described cave development on many levels in the caves of Demänová in Slovakia. The elevations of these levels appeared distinct and relatively constant, and they were assumed to relate to former river courses. Droppa's impressive 
illustration of the supposed situation at Demänová has appeared in various textbooks since then. Likewise, Bögli's (1966) description of cave levels in the Hölloch also assumed a fluvial influence, relating the complex underground situation in this system to stages in the deepening of the Muotatal. Again Bögli's generalized cross-sections have been reproduced elsewhere as acceptable illustrations of the validity of such relationships, and the underlying ideas also seem acceptable within, if not fundamental to, the framework of some modern cave development models.

Worthington (1991) looked at cave levels from a different viewpoint. He used chemical evidence and mathematical arguments to support a suggestion that, at any given time, and subject to rock availability, new conduits forming parts of new tiers will be enlarging in the phreatic zone, beneath any obvious currently active tier. This idea seems to relate in part to concepts within the Inception Horizon Hypothesis of cave development (Lowe, 1992). From one viewpoint this hypothesis can be viewed as supporting the idea of concurrent ongoing development of incipient voids at various pre-determined stratigraphical levels within potentially karstic rock successions. From another viewpoint the initial imprinting of the incipient passage guidance is seen as a process that significantly pre-dates the later, concurrent enlargement. Still more recently, Šušteršič (1998) has observed and discussed "ranks" of channels that can be identified within individual tiers.

Thus, the concept of cave tiers is far from new...but where does the apparent order originate?

\section{CASE STUDIES FROM THE YORKSHIRE DALES, UK}

\section{The western Dales - Casterton Fell to Ingleborough}

\section{The erosion surface model}

Much of Sweeting's 1950 paper was reproduced, essentially unchanged, in textbook format in 1972. The evidence presented dealt with vertical "zones" of cave development right across the Dales area, including western areas such as Casterton Fell, Leck Fell, Kingsdale and parts of Ingleborough (Fig.1). The conception of the study was extremely ambitious and, considering the generally low accuracy of cave survey data available at the time, the results presented and conclusions drawn were creditable. In simple terms the interpretation chosen by Sweeting was that, across the study area, cave passage levels were related to a small number of erosion levels that could be recognized within remnants of planed surfaces adjacent to, or within the long profiles of, the river valleys. To pursue the argument it is necessary to consider just two such surfaces, one lying between 365 and 380m above OD (OD = Ordnance Datum, or "sea-level"), the other between 290 and 305m OD.

As already mentioned, Sweeting's explanation was readily acceptable to many eminent karstologists or general geomorphologists of the day. However, one significant aspect was overlooked, or ignored, in the argument. Whether by accident or design, the Sweeting model omitted the potential for variation within the local geology, apparently assuming that caves would inevitably develop randomly, at any surface-determined level, within a homogeneous limestone mass. It was not until 20 years later that Waltham (1970) provided an alternative, essentially geological, interpretation of the supposed cave levels noted in Sweeting's study area. Existence of this alternative interpretation was acknowledged in Sweeting's (1972) textbook.

\section{Recognition of geological "control"}

Waltham (1970) had the benefit both of first-hand exploration and observation in many caves, some newly discovered, across the Dales. He also had access to a new generation of higher quality cave surveys, on the basis of which he could relate geological features both to absolute levels (relative to OD) and cave passage 


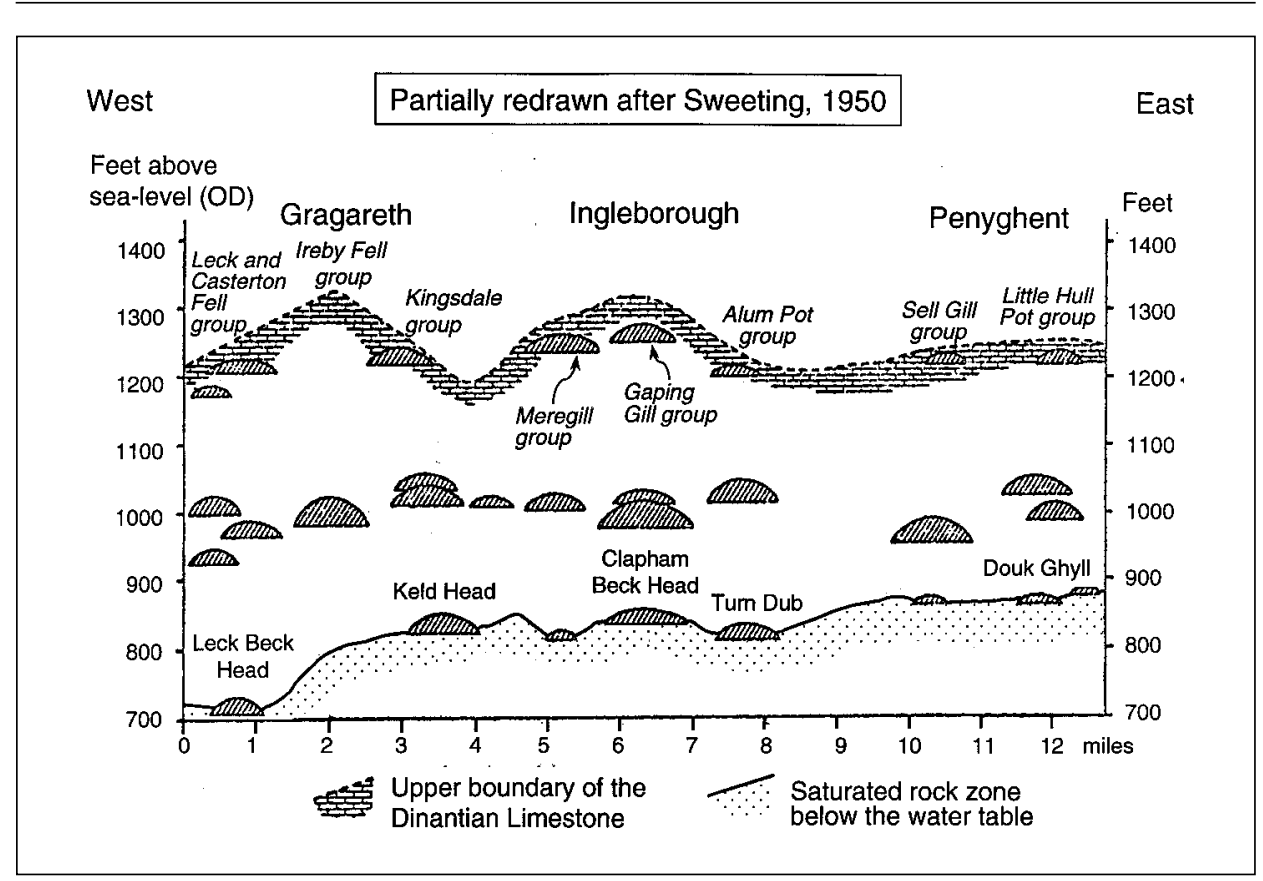

Fig. 1: Schematic cross-section of part of the Yorkshire Dales, showing verical clustering of cave levels. [Modified and partially re-drawn after an original figure by Sweeting, 1950.]

Sl. 1: Shematski prerez dela Yorkshire Dales. Razvidno je kopičenje kanalov na podameznih "nivojih" [Delno na novo risano in modificirano po izvirniku M. Sweetingove, 1950.]

levels. One of the major points that he made was that at least some of Sweeting's so-called erosion surfaces were actually inherited stratimorphs, reflecting geological rather than erosional surfaces. He conceded that erosion surfaces, cutting across highly variable geology did exist locally, but went on to explain why these were not related to cave development levels, at least not in the way that Sweeting had supposed.

By careful observation in the caves, and by reference to cave surveys, Waltham identified "zones" within the otherwise high purity limestone succession that included many "shale beds" (Waltham 1970; 1971):

(a) Locally there is a coincidental agreement between the elevation of Sweeting's cave development zones and that of certain (relatively arbitrary) zones that are rich in shale beds;

(b) The shale-rich zones occur at different absolute elevations in different areas and, hence;

(c) Different shale-rich zones appear to coincide with Sweeting's zones in different areas.

Waltham deduced that the shale beds acted as aquicludes and had a controlling influence on cave development. However this explanation may be incomplete, if not actually incorrect. Waltham also emphasised the significance of faults in causing relative horizontal and vertical displacement of the shale beds within the limestone succession. He also recognised the potential role of gentle rock flexures, particularly those of plunging synclinal form, that acted as sub-surface catchments for water that followed the bedding planes, supposedly above the shale aquicludes. 


\begin{tabular}{|l|r|r|r|r|r|}
\hline & $\begin{array}{c}\text { Easegill } \\
\text { Caverns }\end{array}$ & $\begin{array}{c}\text { Lost } \\
\text { Johns }\end{array}$ & $\begin{array}{c}\text { Ireby Fell } \\
\text { Cavern }\end{array}$ & $\begin{array}{c}\text { West } \\
\text { Kingsdale }\end{array}$ & Gaping Gill \\
\hline 1 & $?$ & $345 \mathrm{~m}$ & $? 390 \mathrm{~m}$ & $370 \mathrm{~m}$ & $? 390 \mathrm{~m}$ \\
\hline 2 to 1 & -- & $65 \mathrm{~m}$ & $60 \mathrm{~m}$ & $55 \mathrm{~m}$ & \multicolumn{2}{|c|}{$? 30 \mathrm{~m}$} \\
\hline 2 & $280 \mathrm{~m}$ & $280 \mathrm{~m}$ & $330 \mathrm{~m}$ & $315 \mathrm{~m}$ & $360 \mathrm{~m}$ \\
\hline 3 to 2 & $52 \mathrm{~m}$ & $60 \mathrm{~m}$ & $60 \mathrm{~m}$ & $50 \mathrm{~m}$ & \multicolumn{2}{|c|}{$50 \mathrm{~m}$} \\
\hline 3 & $228 \mathrm{~m}$ & $220 \mathrm{~m}$ & $270 \mathrm{~m}$ & $265 \mathrm{~m}$ & $310 \mathrm{~m}$ \\
\hline 4 to 3 & --- & -- & & & \multicolumn{2}{|c|}{$50 \mathrm{~m}$} \\
\hline 4 & $?$ & $?$ & $?$ & $?$ & $260 \mathrm{~m}$ \\
\hline
\end{tabular}

Table 1: Comparison of average absolute levels of cave "levels" in five areas of the western Yorkshire Dales, and of the relative vertical distances between them. See also Table 2.

Tabela 1: Primerjava med povprečnimi absolutnimi višinami jamskih "nivojev" v zahodnih Yorkshire Dales relativne višinske razlike med njimi. Glej tudi Tabelo 2.

At about the same time, various authors recognised similar "levels" of cave development in other parts of the Yorkshire Dales, including Easegill Caverns (Ashmead, 1974), Leck Fell (Waltham 1974b), Kingsdale (Brook, 1974) and the Gaping Gill system (Glover, 1974). Most of these levels appeared to be related to shale beds or to other potential aquiclude lithologies. However, some aspect was obviously missing from the commonly held view, which (by use or implication) suggested that shale beds are de facto aquicludes and, hence, all shale beds should act as aquicludes and focus cave development, at least locally. If this were the case, why did only one major level of cave development exist within the span of each of Waltham's shale-rich zones?

Table 1 provides details of the absolute elevation (relative to $\mathrm{OD}$ ) of the major cave development levels in five areas of the western Dales. The values are derived from published cave surveys and hence they are average values. No allowance has been made for variation due to stratal dip or fault displacement within or between individual systems. Minor development levels are ignored and the data are presented system by system in a "counting down" format. The correlation of the data in the final (Gaping Gill) column may be displaced by one level but, as will be described, there are sound geological reasons for assuming that "level 3" is the same in all systems considered, and that at least one more (lower) level exists at Gaping Gill. The table shows that the absolute elevation of levels 1 to 3 varies significantly across the area. However, there is a much smaller variation in the thickness of strata present between levels $1-2$ and levels 2 - 3. Is the relatively constant 


\section{A traditional view}
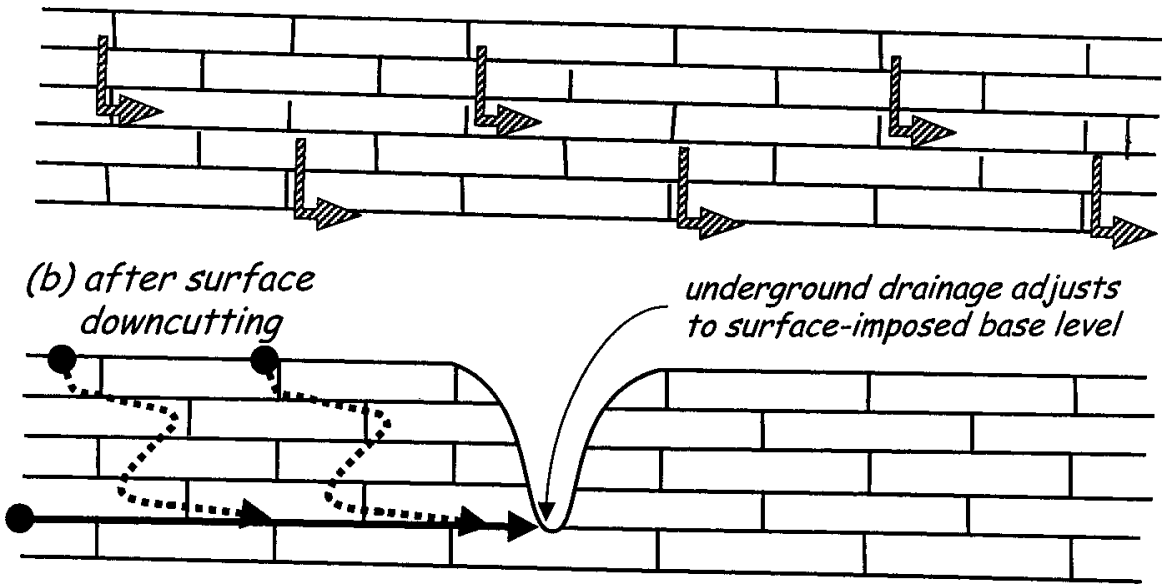

Fig. 2: Simplified and schematic view of one traditional view of underground drainage development by semi-random gravitational percolation. 2(a) shows the situation before the imposition of a modern landscape and 2(b) shows that after surface down-cutting drainage and cave development becomes organized towards valley bottoms.

Sl. 2: Poenostavljen in shematiztiran prikaz enega izmed tradicionalnih pogledov na razvoj podzemske odtočne mreže na osnovi na pol slučajnega gravitacijskega odtoka. Sl. 2(a) kaže razmere pred nastankom sodobnega površja, sl. 2(b) pa kaže, kaj naj bi se zgodilo, ko se vreže površinska odtočna mreža in se razvoj jam usmeri proti dnom dolin.

thickness of limestone (with or without non-carbonate partings) between levels of cave development significant and, if so, why?

\section{Introducing inception horizons}

Figure $2 \mathrm{a}$ is a highly diagrammatic illustration of one common traditional view of cave development within a sub-horizontal limestone sequence. In this view, downward progress of meteoric water is assumed to occur as semi-random gravitational percolation. There is no obvious organization of conduits or sub-conduits, and the logical assumption is that the carbonate mass is effectively homogeneous. In Figure $2 b$, a surface valley is superimposed onto the limestone mass, with its semi-random void system. Drainage within the mass will now target on a point (or points) in the valley bottom, which takes on the role of local base level. Elements of the pre-existing semi-random void system then begin to become organised and to develop in preference to less favourable elements within the rock mass. However, as solid limestone is commonly less porous than, say, granite, how can either stage of the traditional view be valid? Though many objections could be raised 


\section{An alternative view}
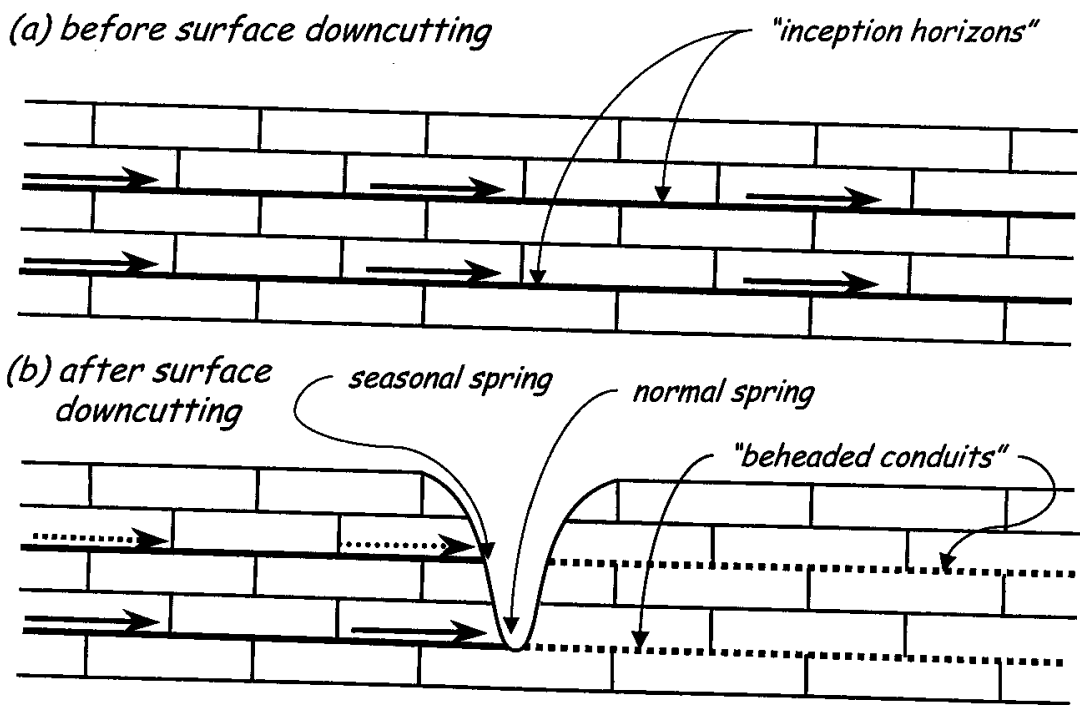

Fig. 3: An alternative view of how cave organization progresses. 3(a) shows that early drains develop down the geological gradient, along "inception horizons". 3(b) shows the situation that develops as a result of ongoing surface down-cutting.

Sl. 3: Alternativen pogled na nastajanje organiziranega jamskega spleta. Sl. 3(a) kaže, da se prvi odtok oblikuje po vpadu skladov vzdolž “začetnih horizontov”. Na sl. 3(b) pa so razmere, ki nastanejo kot posledica napredujočega zniževanja površja.

(and countered) regarding this highly simplified view and its dismissal, it serves as a contrast to the following ideas.

Figure $3 \mathrm{a}$ is an equally diagrammatic alternative view of the same situation. In this case it is suggested that underground movement of meteoric water in the pre-downcutting situation is already organized to some extent. The primitive organization is related to development down the geological gradient (in this case the slight dip of the bedding) within a limited number of favourable beds. The latter are described as "inception horizons", as will be explained elsewhere, but at this stage of the argument shale beds functioning as aquicludes, as proposed by Waltham $(1970,1971,1974)$ could equally well be responsible. Imagining now that a valley begins to incise into the limestone (Fig. 3b) it is clear that the higher inception horizon will be intersected first. Ignoring the (equally interesting) potential effects on the down-dip side of the valley, the immediate result is development of a spring on the up-dip side. While this spring functions and conduit development becomes still more organized towards it, the lower inception horizon continues to function, with its (perhaps reduced) drainage passing beneath the valley floor. Subsequently, as downcutting continues, a new spring develops related to the lower inception horizon. The higher spring is abandoned by all but local percolation and, perhaps, flood overflow water. None of this is new, and similar ideas were raised by Gardner as long ago as 1935. 


\section{Not to scale}

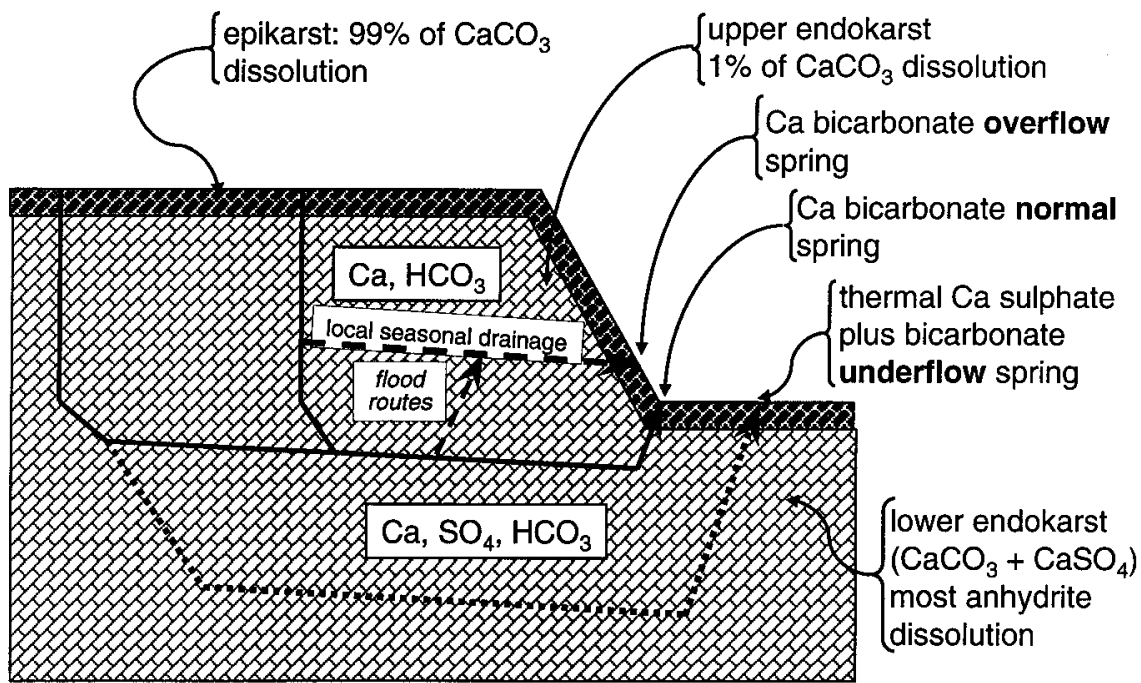

Modified after figures by S R H Worthington, 1991 (modifications are the present author's responsibility).

Fig. 4: Conceptual view of different dissolutional regimes and different levels of underground drainage (and void development) in a limestone mass. [Compiled and modified from various original figures by Worthington, 1991.]

Sl. 4: Konceptualni pogled na različne režime raztapljanja na različnih "nivojih” podzemskega odtoka (in razvoja kanalov) znotraj apnenčeve gmote. [Sestavljeno in modificirano po različnih izvirnih skicah S. Worthingtona, 1991.]

Clearly, any early voids imprinted along the inception horizons down-dip of the valley will continue to exist. They they may become blocked by sediment, they may act as sinks for some of the surface water, they may gather percolation from the overlying limestone mass, and any number of other potential combinations that will depend upon the void size, the surface flow and the rate of surface downcutting. Depending upon the resistance further down-dip along the original geological/hydraulic gradient, they might even function as estavelles.

The situations shown in Figures 2 and 3 are simplistic in the extreme, yet they serve to illustrate the potential role of "favourable beds". The view presented is perhaps the simplest case of the stratigraphical guidance of conduit development described within the Inception Horizon Hypothesis (Lowe, 1992). Where good geological data are available, far more complex situations involving folded and faulted sequences can be modelled equally successfully, and the secondary role of various types of fractures forms a complementary component of more true-to-life models.

Worthington (1991) deduced on mathematical and chemical grounds that, within a single catchment, drainage can move simultaneously on several different levels. Figure 4 includes aspects of several of his original drawings. It shows schematically that at any given time conduit systems may exist at more than one 


\begin{tabular}{|c|c|c|c|c|c|}
\hline $\begin{array}{c}\text { Position of } \\
\text { inception horizon }\end{array}$ & $\begin{array}{l}\text { Easegill } \\
\text { Caverns }\end{array}$ & $\begin{array}{l}\text { Lost } \\
\text { Johns }\end{array}$ & $\begin{array}{c}\text { Ireby Fell } \\
\text { Cavern }\end{array}$ & $\begin{array}{c}\text { West } \\
\text { Kingsdale }\end{array}$ & Gaping Gill \\
\hline $\begin{array}{l}\text { [Base Brigantian] } \\
\text { Top Asbian }\end{array}$ & $?$ & $345 m$ & ?390m & $370 \mathrm{~m}$ & $390 \mathrm{~m}$ \\
\hline strata between & -- & $65 m$ & $60 \mathrm{~m}$ & $55 m$ & $30 m$ \\
\hline Mid-Asbian & $280 m$ & $280 m$ & $330 m$ & $315 \mathrm{~m}$ & $360 m$ \\
\hline strata between & $52 m$ & $60 \mathrm{~m}$ & $60 m$ & $50 \mathrm{~m}$ & $50 m$ \\
\hline $\begin{array}{l}\text { (Porcellanous Bed) } \\
\text { Base Asbian } \\
\text { [Top Holkerian] }\end{array}$ & $228 \mathrm{~m}$ & $220 \mathrm{~m}$ & $270 m$ & $265 \mathrm{~m}$ & $310 \mathrm{~m}$ \\
\hline strata between & -- & -- & -- & -- & $50 \mathrm{~m}$ \\
\hline $\begin{array}{l}\text { ? Mid-Holkerian } \\
\text { [boundary between Cove } \\
\text { and Kilnsey limestones] }\end{array}$ & $?$ & $?$ & $?$ & $?$ & $260 \mathrm{~m}$ \\
\hline
\end{tabular}

Table 2: The same data that are shown in Table 1, but relating the cave "levels" to inception horizons.

Tabela 2: Isto kot na Tabeli 1, le da se "jamski nivoji” ozirajo na začetne horizonte.

level within a carbonate mass. $99 \%$ of calcium carbonate dissolution takes pace in the relatively thin epikarstic zone, with most of the remaining $1 \%$ occurring in the upper endokarst. Within the lower endokarst, mass loss is achieved by dissolution of calcium sulphate. It is self evident that, as surface downcutting progresses, rocks in an originally lower endokarst situation will migrate first into the upper endokarst and then into the epikarstic zone. Thus, most, if not all, calcium sulphate will be removed from carbonate successions before erosion brings them close to the surface.

\section{Returning to the western Yorkshire Dales}

On the basis of fieldwork and consideration of published accounts, Lowe (1992) recognised that the three levels of cave development ( 1 - 3) described in Table 1 related to specific stratigraphical horizons within the local Dinantian limestone succession. Not only that, but all three lay within (or at the boundaries of) a single major depositional cycle, which is coincident with the British Asbian Stage. Table 2 relates the three previously described cave development levels to the specific horizons in question.

The top of the Asbian Stage (major cycle 5) is marked by subaerial deposits that locally include a thin coal seam. Its base is marked by the regressive beds that closed the depositional activity of the underlying Holkerian Stage, and these include a distinctive micritic limestone known as the Porcellanous Bed. It is this bed, which 
is easily recognisable between Casterton and Leck as well as in Kingsdale and the Gaping Gill system, that seems to confirm the correlation of the three Gaping Gill levels with those farther west. Between these two distinctive horizons at the upper and lower limits of the Asbian Stage is a third, equally obvious, horizon (the Mid-Asbian Break). This is marked by all or some of a high-relief palaeokarstic surface, a shale bed that locally reaches $2 \mathrm{~m}$ in thickness, pseudobreccias and local enrichment in shell debris. All of these latter are indicative of a hiatus between two (in this case minor) depositional cycles.

This situation alone is insufficient to confirm the specific significance of these particular horizons (and to a large extent only these horizons) to the guidance of cave development. Asbian horizons are only three among more than fifty bedding plane discontinuities within the ten minor cycles that comprise major cycle five. When looked at in this way, it is clear that the three inception horizons must exhibit especially favourable properties. Similar properties are either not evident along the other fifty bedding planes, or they may be so feebly presented that the host weaknesses are unable to compete for void development favourability. Various potential explanations of the role of inception horizons were discussed by Lowe (1992) and subsequently reiterated by Lowe and Gunn (1997), but more recent indications suggest that the initial imprinting of inception horizons may be even more fundamental.

\section{Summing-up the western Dales situation}

There is strong observational evidence that the great majority of cave development across the western Dales from Casterton Fell in the west, at least as far eastwards as the Gaping Gill system, has been guided by only three stratigraphical horizons. Throughout the area a role for faults (many more than are shown on published geological maps) and joint fractures is equally evident, providing the guidance of shafts that form physical and hydrological links between the three inception horizons or between fault-translocated elements of the same horizon. It is not coincidental that at least two of the major resurgences in the area (Leck Beck Head and Keld Head) are located on the basal Asbian (more correctly Top Holkerian) Porcellanous Bed horizon. The role of minor plunging synclines in guiding the location of major drains at the levels of the inception horizons is equally clear. On Leck Fell the active main drain of Short Drop Cave follows the uppermost inception horizon, while $120 \mathrm{~m}$ beneath it the main drain of Lost Johns Cave follows the Porcellanous Bed horizon within the same structure. Fragments of major abandoned passages follow the fold in the intervening inception horizon. Such relationships would not be expected if cave development were controlled only by surface phenomena. A similar situation exists in the Easegill system beneath Casterton Fell, though here the higher of two superimposed main drains is now abandoned. Elsewhere, similar gentle synclines have guided major passage developments in caves such as Notts Pot and Ireby Fell Cavern. Tributary streams flow down-dip into the synclines, whereas the intervening anticlinal areas provide gathering grounds and underground watersheds between individual cave systems. The anticlinal zones are marked on the surface either by valleys with many sinks (such as that of Easegill Beck), or by linear concentrations of karst depressions, known locally as "shakeholes", each developed above an upward widening fracture.

\section{West and east of Ribblesdale}

\section{Introduction}

Moving eastwards to Ribblesdale several apparently discrete underground drainage systems lie within a similar part of the Dinantian succession, though penetrating down into older limestones that overlie a Lower Palaeozoic basement. Their guidance, at least in part, can be related to the same horizons recognised in the western area. Here however, natural development of the extensive cave passages beneath the area has been interrupted and partly "frozen in time" by the imposition of non-karstic (in this case glacial) processes. Additionally, as is certainly the case elsewhere in the Dales, stratigraphically lower inception horizons must exist, whether or not they are currently intersected by the modern land surface. The influence of the basement rocks also becomes apparent, but perhaps not in the way that traditional karst models would suggest. 


\section{Background}

Around the village of Horton in Ribblesdale the Ribble valley has been deeply incised by late Pleistocene glacial processes. North of the village the valley is still floored by carbonates, which are probably faulted down relative to similar rocks farther south. In the valley floor to the south the Dinantian rocks have been gouged away to reveal a structurally complex set of Lower Palaeozoic clastic rocks. Similar, though less extreme, effects produced another inlier of Lower Palaeozoic rocks in the valley of Crummack Dale, to the west.

East of the Ribble, underground drainage from areas east and southeast of the village has been traced to one or more of three linked resurgences at Brants Gill, Douk Ghyll and Dub Cote. Of these only Dub Cote has any extensive accessible passages, mostly explored only by divers. Water from Sell Gill Holes and other sinks nearby resurges at Newhouses Spring, welling upwards through alluvium in the valley floor north of the village. Between this system and that east of Horton in Ribblesdale, several minor caves resurge at relatively high level from the side of a glacially over-deepened side valley. Similarly, many relatively shallow caves north of Sell Gill Holes carry water northwards, where it emerges, again at relatively high level, from various caves in the steep, glacially cut, side of the Ribble valley. The systems in this area have no known connection to another major rising, Turn Dub, which lies on the eastern bank of the Ribble, $1 \mathrm{~km}$ north of Newhouses Spring.

Looking now to the west of the Ribble, considerable underground drainage gathered from Washfold Pot and shallow caves that feed towards Alum Pot emerges first in a pool at Footnaw's Hole, west of the Ribble. However, at least part of the flow continues beyond Footnaw's Hole, passing beneath the Ribble, to resurge at Turn Dub on the opposite bank. On the southern part of Simon Fell, water from several sinks has been traced to Austwick Beck Head in the floor of Crummack Dale. Also west of the Ribble are two smaller caves, Blind Beck and Ringle Mill. Blind Beck discharges a stream for most of the year, but in wet weather the flow increases and there is vastly increased output from Ringle Mill. With no known allogenic feeders, both caves have been assumed to transmit autogenic input from the bare limestone plateau to the west, but this might be only part of the full picture.

Hydrological and morphological relationships are complex. There are gaps in knowledge of the underground systems and details of the local geology are also incomplete. Available geological maps pre-date modern understanding of the stratigraphy of the main cavernous sequences, and they show few faults and give no indication of minor fold structures.

\section{A potential explanation}

The uppermost sub-horizontal passages in most of the caves that feed to the Ribble valley and Crummack Dale springs are related to the Top Asbian inception horizon (described above), which is locally offset by faults. The deeper systems that feed to Brants Gill, Douk Ghyll, Dub Cote, Newhouses Spring, Turn Dub and Austwick Beck Head, penetrate via faults and joints to lower inception horizons. However the situation relating to these deeper systems and their resurgences is far from simple.

In contrast, the shallow systems, including those north and southeast of Sell Gill Holes, are also guided by this stratigraphically high inception horizon, locally marked by a mudstone bed (Dyson, 1969). It is locally offset by faults and deformed into minor W-E folds. These systems terminate where glacial erosion has removed the original continuations of their guiding inception horizons at points "upstream" of where, potentially, they could have dropped to lower inception horizons. Illustrations of the original situation are provided by the upper parts of some of the deep eastern systems, and more dramatically by sub-horizontal caves that feed to and towards Alum Pot. Here, the quantum jump to lower inception horizons is achieved via the Alum Pot fracture system. Thus these shallow caves are relict fragments of once far more extensive and complex inception systems that have been left perched due to the accelerated effects of glacial downcutting. No clear detail of either pre-glacial flow directions or pre-glacial continuations remains.

Returning to the deeper systems it is most productive to consider the resurgences. Of the three springs 
east and southeast of Horton, only Dub Cote Cave lies at the position that traditional wisdom suggests - that is, at the unconformity between the clastic basement and the earliest limestones. Paradoxically, this stratigraphically lowest outlet also has the smallest flow under most conditions. Douk Ghyll and Brants Gill lie slightly above the unconformity and are related to subaerial deposits within a condensed sequence of partial depositional cycles, probably close to the contemporary Dinantian shoreline. These resurgences, whether above or on the unconformity, all lie below the stratigraphical level of the three main inception horizons discussed above.

Under normal conditions Brants Gill has a steady output and Douk Ghyll is almost dry, but in wetter conditions Brants Gill's flow increases only marginally and Douk Ghyll emits a flood flow. The three rising are obviously related, probably via flooded up-dip routes developed predominantly along bedding planes behind the risings. Their different flow regimes may relate to the pre-glacial existence of primitive but laterally extensive routes along several "weak" inception horizons low in the Dinantian sequence, or to fault transposition of development along only one or two favourable horizons. Unroofing of the routes by glacial downcutting established the immature resurgences whose dimensions and state of drainage are still out of phase with explorable caves at higher levels.

Sell Gill Holes is an oddity. Glacial erosion appears to have removed its upper levels as well as part of its pre-glacial lower levels. High level bedding-guided passages remain, solidly blocked by glacial debris, but stratigraphically these are significantly below the Top Asbian inception horizon, and most of the overlying sequence has been removed. The main development is vertical, following a major fracture set, but at the bottom of the cave a sub-horizontal trend is again apparent. Drainage from the cave probably enters a flooded conduit that originally crossed the Ribble valley but was unroofed by glacial action. At Newhouses Spring drainage leaks upwards through glacial deposits and modern alluvium. As with Turn Dub (below), it appears that Newhouses Spring is a window into (or out of) an inception horizon carrying very deep drainage downdip from west to east under the Ribble. The fact that drainage from Sell Gill Holes and other nearby sinks moves up-dip to emerge here suggests that the onward easterly inception route remains very immature and constricted, with high flow resistance.

Part of the system draining to Footnaw's Hole and Turn Dub has been described above as providing an indication of earlier situations east of the Ribble. Drainage now passes from the highest inception horizon, down the Alum Pot fracture zone, to find lower inception horizons, which extended across the Ribble valley prior to glacial incision. In this case the pre-existing hydraulic (and geological) gradient was certainly from west to east, as drainage still follows a route deep enough to pass beneath the modern river, from Footnaw's Hole to Turn Dub. Assuming that the gradients continue, Turn Dub is the last point at which an artesian lift can be achieved before the inception horizon passes beneath the thick Dinantian sequence preserved to the east. As the Top Asbian inception horizon outcrop is high in the eastern wall of Ribblesdale, it may be that the beds carrying drainage beneath the river are relatively downfaulted segments of the Mid or Basal Asbian inception horizons. Detailed study is needed.

Water sinking south of the Alum Pot catchment now flows to Austwick Beck Head. However, the rising is very immature, lying close above (but not directly on) the basal unconformity, and it could not have existed before the last glaciation. Evidence of prodigious glacial scouring exists in the Lower Palaeozoic floor of the valley, where glacial striae are common, and in the form of huge numbers of plucked boulders of Lower Palaeozoic material that litter the valley floor and sides. So, what was the pre-glacial route of drainage from the limestone mass that now feeds Austwick Beck Head?

At least part of the drainage took shallow, bedding-guided, routes down the geological gradient towards the east, perhaps within the Top Asbian inception horizon. A smaller component probably exploited the two deeper Asbian inception horizons, moving in the same general direction. The upper part of the succession on the Crummack Dale - Ribblesdale interfluve was then planed away by glacial activity, and the Top Asbian inception horizon, at least, was lost. Lower inception horizons almost certainly survived, though truncated locally by the glaciers. They will have changed little since glacial times, as their original feeder routes have been diverted towards Austwick Beck Head. The overlying plateau has no allogenic streams, only meteoric 
input via the bare limestone surface. Both Blind Beck and Ringle Mill caves lie at the level of the Basal Asbian inception horizon, and are probably windows into original down-dip drainage routes from the west. Conduits immediately behind Austwick Beck Head are immature and constricted, so in very wet conditions water probably backs up above the rising. There may then be underground overflow eastwards, along the higher level primitive, pre-glacial, inception routes. This would account for the spectacular floods that are periodically encountered at Ringle Mill Cave.

If this explanation is viable, it is tempting to wonder whether the original regional hydraulic gradient for the whole of this area was from west to east, continuing not only beneath the pre-glacial Crummack Dale but also beneath proto-Ribblesdale. If so it might be that the northwestward routes currently followed by water sinking on Fountains Fell towards the Horton risings is a reversal of the original regional trend. Corroborative evidence is provided by the fact that water trace velocities from the Fountains Fell sinks are an order of magnitude less than those from the Penyghent area.

\section{Summing-up the Ribblesdale situation}

Pre-glacially, deep underground drainage could have followed at least three immature inception routes generally from west to east, passing beneath the current Crummack Dale and Ribblesdale valleys. The regional hydraulic gradient being followed was very slight, and its continuation followed equally low efficiency buried routes, off the dominant Pennine anticlinal structure and towards the basinal area to the east. This situation pre-dated the geologically instantaneous development and overdeepening of Ribblesdale and Crummack Dale.

Post-glacially the land surface had locally incised through the previously buried void systems, each associated with a specific inception horizon, and had locally unroofed the impermeable basement. The former regional hydraulic gradients were cut into smaller local fragments, most noticeably at the uppermost inception levels. In the west the higher beds with their more efficient drainage routes were stripped away completely. Incipient routes below, passing eastwards towards Blind Beck and Ringle Mill caves, were preserved but inefficient.

Thus, underground drainage routes from the west were constricted and within the ponded-back situation that developed, newly advantageous, perhaps fracture-dominated routes, were established, targeted upon a structural low point at the newly exposed basal contact of the limestone at Austwick Beck Head. Even here a favourable bedding component been involved - the resurgence passage is bedding - guided and lies a short distance above the actual basal contact. Other immature bedding-plane seepages at a similar horizon but structurally higher level occur along the western (up-dip) side of Crummack Dale, suggesting that the rock mass is effectively saturated. Austwick Beck Head provides an inefficient but structurally focussed low point, from which most of the area's underground water escapes under normal conditions.

To the north a significant thickness of limestone survives, crossing the interfluve towards Ribblesdale. Primitive pre-glacial void systems associated with at least the Basal Asbian (Porcellanous Band) inception Horizon and possibly the Mid-Asbian horizon extend eastwards. Though unconfirmed by tests, it is possible that flood water from the western sinks can back up behind the immature route to Austwick Beck Head, and spill along the primitive low gradient routes towards Ribblesdale. These normally carry autogenic water to Blind Beck Cave and (to a lesser extent) to Ringle Mill, but in wet weather the flow at Ringle Mill (in particular) increases dramatically. It is tempting to speculate further about where the pre-glacial continuations of these passages might lie on the eastern side of Ribblesdale, but geological detail is as yet insufficient to allow even a tentative guess.

Pre-glacially, many metres of rock lay above the current floor of Ribblesdale, so the present resurgences did not exist. Deep water movement must have continued eastwards and southeastwards down the regional geological/hydraulic gradient. Most of this regional transfer must have entered buried basins to the east, whereas a proportion might have reached the surface along major block margin fault zones to the south, depending upon their own stage of unroofing. As with the more local drainage routes discussed above, the overall hydraulic gradients were very slight. 
Glacial down-cutting cut windows through some of these long and deeply buried routes. Shallow parts of the systems to the west were planed away (as described above) while deeper sections continued to function. In the east shallow systems now disgorged their drainage high on valley sides from the truncated ends of (probably) the highest (Top Asbian) inception horizon. The incipient voids that gave rise to the deep systems of Penyghent remained unaffected by glacial erosion, though drainage that might originally have followed regional routes towards the east was readily pirated to the deeper and newly intersected inception horizons that support the risings east of Horton. The flooded or epiphreatic state of the deepest parts of these caves emphasises that even after 10,000 years the routes to the new risings remain immature.

The ancestral voids of the deep caves of Fountains Fell also lay originally on the buried regional hydraulic gradient moving water generally eastwards. Perhaps a minor flexure cuts across the route, so that water was driven locally up-dip by the artesian pressure head from the west. If so, once the valley had cut down, drainage must have reversed to move down-dip towards the Horton risings. Even if no flexure exists water may be driven unfavourably up-dip, back towards Horton. This could explain the order of magnitude difference between flow rates from Penyghent and those from Fountains Fell. In any case, an underground watershed (perhaps a gentle anticline) lies somewhere in the region of the southeastern limits of Magnetometer Pot, which is a system renowned for its complex hydrology, with low and immature bedding plane passages and a confusing profusion of sumps.

These considerations provide a new, as-yet unsubstantiated, view of the underground drainage between Simon Fell and Fountains Fell. Assumption of pre-modern landscape deep flow and the presence and early guiding role of inception horizons allows a much more reasoned explanation of the known situation than do assumptions of random flow within all stratigraphical or structural fissures. On the basis of the theoretical model, predictions about the positions of abandoned pre-downcutting voids and unroofed caves could now be made.

\section{INCEPTION HORIZONS AND UNROOFED CAVES}

Despite the above detailed consideration of the potential role of inception horizons (or perhaps simply "favourable beds") across a wide swathe of the Yorkshire Dales, caves do not provide the ideal means of recognizing such features. In natural caves erosion and weathering may obscure the crucial relationships, especially where vadose entrenchment has incised deep canyons below original guiding horizons. Similar things can be said of natural cliffs and valley walls. Newly opened artificial excavations - such as quarries and road cuttings - provide some of the best evidence for the widespread occurrence of potential cave development horizons and the occurrence of the many more discontinuities that are less advantageous.

In a quarry in the Derbyshire Peak District, about $100 \mathrm{~km}$ south of the Yorkshire Dales, appears a sub-horizontal sequence of bedded, high-purity, Dinantian limestone. More than $60 \mathrm{~m}$ of beds can be seen in two quarry faces, one above the other. Among the many bedding planes visible (average spacing 1 to $2 \mathrm{~m}$ ) only two are conspicuous, one roughly in the middle of each face. Two points should be noted. First of all the entire extent of the bedding plane is perforated by low but wide (ie bedding-guided) dissolutional cavities. This illustrates that inception activity potentially affects the full width of suitable bedding planes, although following eventual exposure ongoing enlargement may be concentrated in local structural lows. Secondly, the rock below the bedding plane is stained by iron-rich solutions, probably derived by breakdown of pyrite (iron sulphide) within impurities associated with the bedding parting. Such breakdown commonly also produces sulphuric acid, a highly efficient dissolutional agent, and at least one type of inception horizon appears to gain its 
advantage in this way. Similar observations relate to the upper quarry face bedding plane, and similar exposures are common in many other limestone quarries.

A further $150 \mathrm{~km}$ to the south, the Dinantian limestone sequence of the Forest of Dean also contains a limited number of inception horizons among many visible bedding planes. Favourable beds are seen in active caves as well as in relict caves and in iron-ore mines (Lowe, 1993). The ore was emplaced into pre-existing but partially buried caves during Triassic times, and the ore bodies were subsequently exposed along the limestone outcrop as the surface landscape developed. Figure 5 , partly schematic but based on available mining records, shows the relationship of the ore bodies to the stratigraphy. Old outcrop workings actually represent an organised system of ancient, now unroofed, caves. Elsewhere in the Forest of Dean unroofed caves showing features comparable with those described in Slovenia are also found in areas that were unaffected by iron-ore deposition.

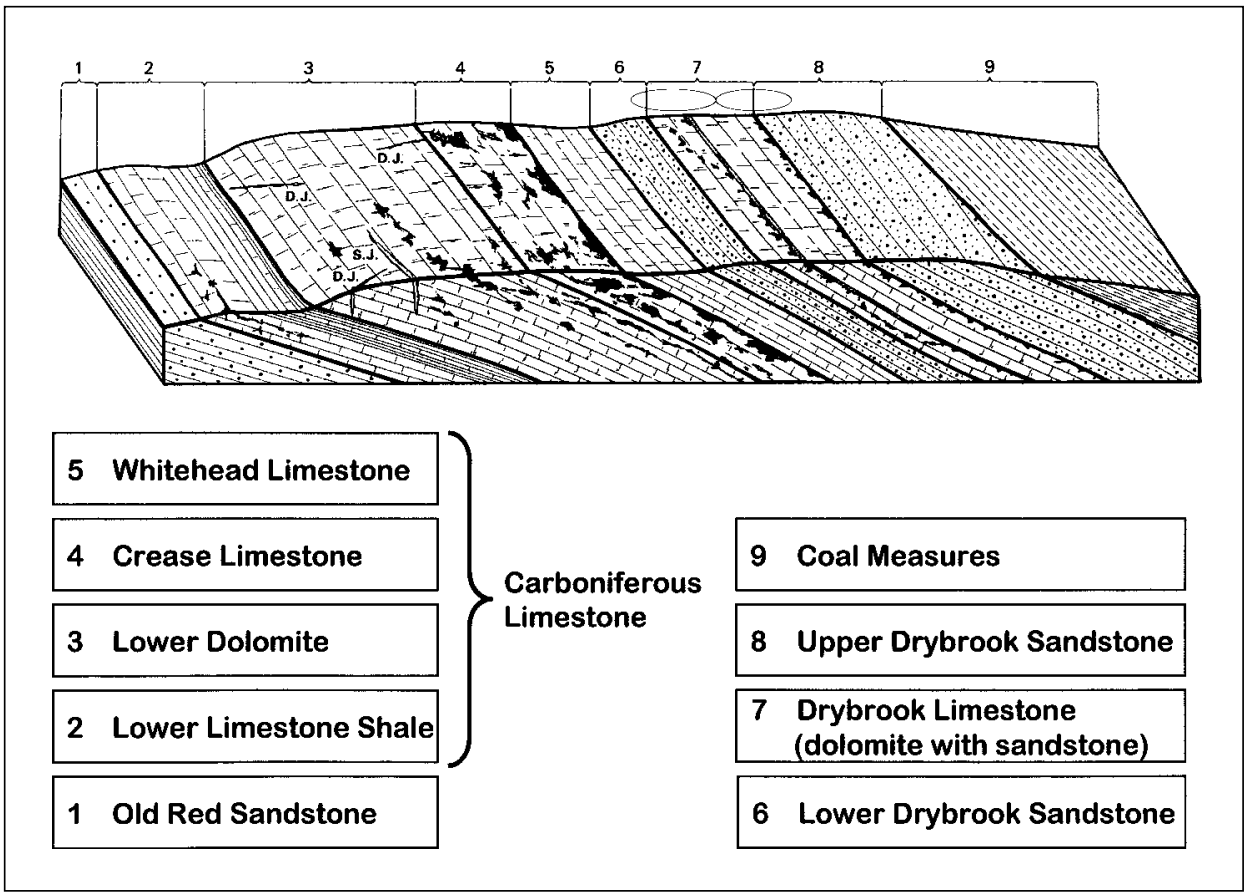

Fig. 5: The relationships of iron-ore workings in part of the Forest of Dean (UK) to the stratigraphy. Ore was emplaced in pre-existing caves during the Triassic and the surface outcrops of the orebodies represent unroofed caves. [Modified from Figure 35, British Regional Geology: Bristol and Gloucester region. ONERC. Source the British Geological Survey.]

Sl. 5: Odnosi med železnimi orudenji in stratigrafijo v delu Forest of Dean (UK). Ruda se je v triasu odložila $v$ že obstoječe jame in današnji površinski izdanki so dejansko brezstrope jame. [Modificirano po Figure 35, British Regional Geology: Bristol and Gloucester region. CNERC. Source the British Geological Survey.] 


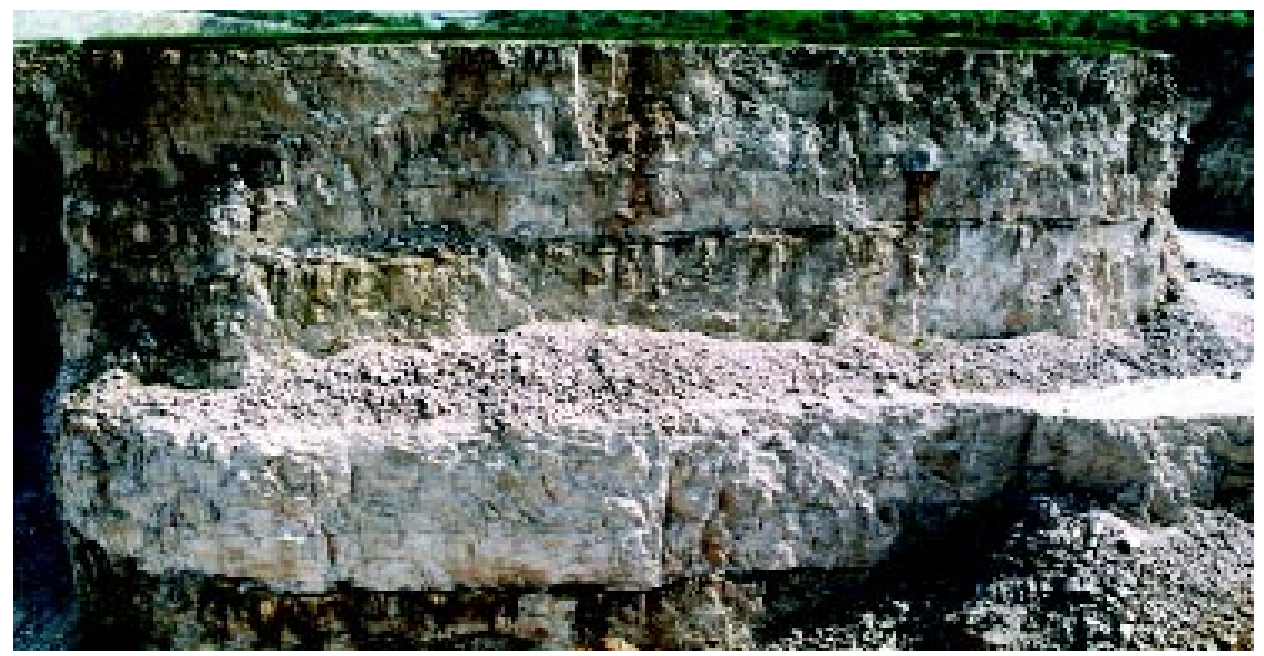

Fig. 6: Part of the bedded Carboniferous limestone succession in a Derbyshire (UK) quarry. Each face is about $30 \mathrm{~m}$ high and throughout the two faces the spacing of bedding planes is 1 to $2 \mathrm{~m}$. Only one bedding plane on each face level shows signs of strong dissolutional activity.

Sl. 6: Del palstovite skladovnice karbonskega apnenca v kamnolomu v Derbyshireu (UK). Vsako čelo je visoko okrog $30 \mathrm{~m}$ in v obeh čelih so lezike razmeknjene za 1 do $2 \mathrm{~m}$. Samo po ena lezika na vsaki etaži kaže znake močne korozije.

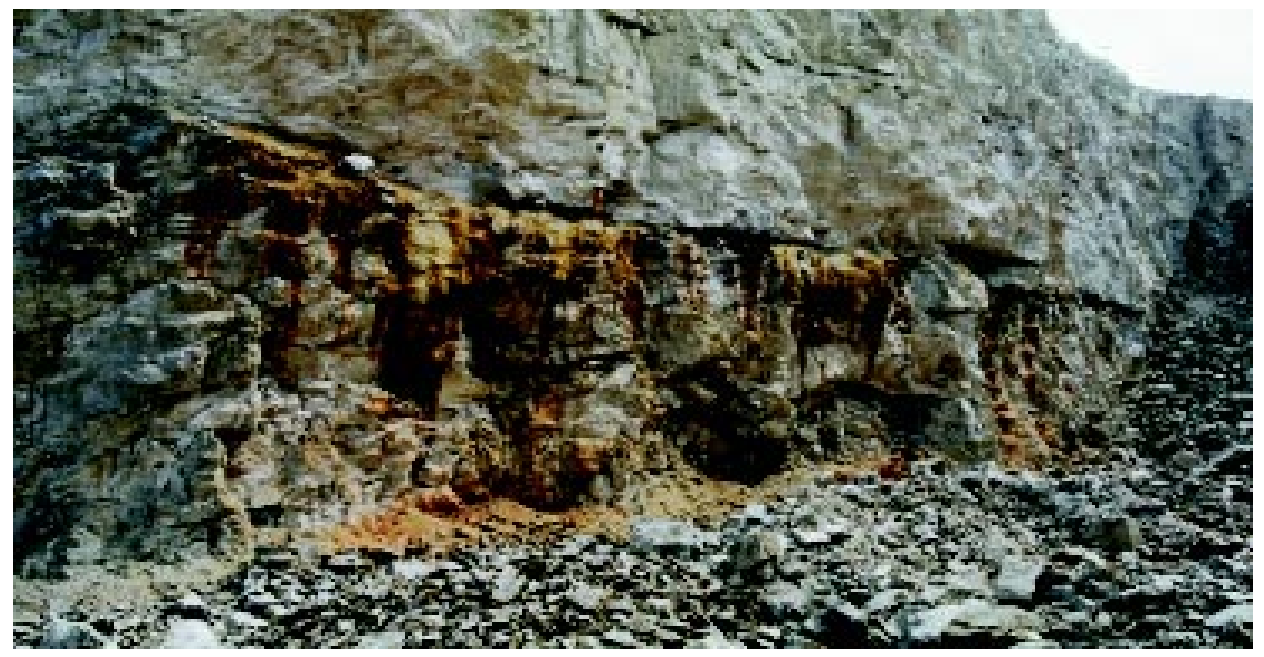

Fig. 7: A closer view of the lower face seen in Figure 6. The dominant bedding plane displays laterally extensive dissolutional voids and the rock below the bedding plane id heavily iron-stained. Sl. 7: Bližnji pogled spodnjega čela (sl. 6). Dominantna lezika kaže bočno razširjene korozijske kanale. Kamnina pod leziko kaže prevleke železa. 


\section{POINTS TO NOTE}

On the basis of aspects described in detail or only touched upon above, the following points should be noted:

- Identical horizons guide cave development at different altitudes across wide areas:

$\Rightarrow$ This would not be expected unless early cave development pre-dated the present landscape or base level.

- Elements of these horizons guide cave segments even in steeply dipping and faulted rocks:

$\Rightarrow$ This would only be expected if they offered significant advantages for dissolutional void development before modern "water-tables" existed.

- No rock stratum is totally homogeneous, even a bed that is described as "massive". Each bed records a sequence of varied but somehow inter-related events and differences across bedding planes or even apparently within beds may acquire local or regional significance:

$\Rightarrow$ The inception horizons (or favourable beds) in any given sequence will be the small number of beds (commonly 1 to $2 \%$ ) that display properties making them significantly more advantageous to void development than their more numerous neighbours. Thus, factors that make a bed favourable in one sequence might not be favourable in a different sequence.

- If, as claimed by Worthington (1991) there is simultaneous dissolution at several levels, and if

- Higher dissolutional cave levels can be left un-modified as drainage drops to lower, pre-existing, voids after uplift:

$\Rightarrow$ Elements that guide, carry out and drive early dissolutional void development must be in place and active before uplift, and before imposition of modern landscapes.

- The Inception Horizon Hypothesis of cave development (Lowe, 1992) suggests that incipient, basin-wide, startigraphy related, weaknesses are imprinted within carbonate sequences during or soon after diagenesis, and certainly pre-tectonically. These guide later cave growth within structurally guided "zones" that lie along evolving hydraulic gradients:

$\Rightarrow$ Strong sedimentological evidence supporting this suggestion has been observed by France Šušteršič (1999) and his colleagues on Mount Krn in Slovenia.

\section{IN CONCLUSION}

- Whether in sub-horizontal of folded beds, cave "organization" is linked primarily to stratigraphy;

- In many cases the "favoured" bedding planes correspond to depositional cycle boundaries;

- Inception of void development along favoured bedding planes (inception horizons) commences during diagenesis and, hence, is pre-tectonic;

- Subject to collection of the required geological information, awareness of the above enables prediction of Present patterns of cave organization on the basis of Past events. 


\section{ACKNOWLEDGEMENTS}

Thanks to Tadej Slabe and the Karst Research Institute (Postojna) for their invitation to make a presentation at the $7^{\text {th }}$ Karstological School, and to Professor John Gunn, of the Limestone Research Group at Huddersfield University for supporting my travel. Special thanks to France Šušteršič, Tadej Slabe and Andrej Mihevc for introducing me to "roofless caves" and accepting my pedantic alternative term "unroofed caves". My stay in Slovenia was made even more pleasant by the hospitality of France Šušteršič, his family and their friends.

\section{REFERENCES}

Ashmead, 1974. Development of the Caves of Casterton Fell. 250-272 in Limestones and Caves of North-West England. Waltham, A C (editor). (Newton Abbot: David and Charles.)

Brook, D, 1974. Cave Development in Kingsdale. 310-334 in Limestones and Caves of North-West England. Waltham, A C (editor). (Newton Abbot: David and Charles.)

Dyson, N, 1969. The Meal Bank Coal Seam and its influence on cave development. Bradford Pothole Club Bulletin, Vol.5, No.6, 16-18.

Egemeier, S J, 1981. Cavern development by thermal waters. National Speleological Society Bulletin, Vol.43, 31-51.

Gardner, J H, 1935. Origin and development of limestone caverns. Bulletin of the Geological Society of America. Vol.46, 1255-1274.

Glover, R R, 1974. Cave Development in the Gaping Gill System. 343-384 in Limestones and Caves of North-West England. Waltham, A C (editor). (Newton Abbot: David and Charles.)

Krothe, N C and Libra, R D, 1983. Sulfur isotopes and hydrochemical variations in spring waters of southern Indiana, U.S.A. Journal of Hydrology, Vol.61, 267-283.

Lowe, D J, 1992. The origin of limestone caverns: an inception horizon hypothesis. Unpublished PhD Thesis, Manchester Metropolitan University.

Lowe, D J, 1993. The Forest of Dean caves and karst: inception horizons and iron ore deposits. Cave Science, Vol.20, No.2, 31-43.

Lowe, D J and Gunn, J, 1997. Carbonate speleogenesis: an inception horizon hypothesis. Acta Carsologica, Vol.26/2, 457-488.

Mihevc, A, 1998. A roofless cave near Povirje and denuded caves in the vicinity of Divača [in Slovene with English abstract]. Geografski obzornik, Vol.45(2), 12-17.

Sando, W J, 1988. Madison Limestone (Mississippian) paleokarst: a geologic synthesis. 256-277 in Paleokarst. James, N P and Choquette, P W (editors). (New York: Springer Verlag.)

Šušteršič, F, 1998. Interaction between a cave system and the lowering karst surface. Case study: Laški Ravnik. Acta Carsologica, Vol.27/2, 115-138.

Sweeting, M M, 1950. Erosion cycles and limestone caverns in the Ingleborough district. Geographical Journal, Vol.115, 63-78.

Sweeting, M M, 1972. Karst Landforms. (London: Macmillan.)

Waltham, A C, 1970. Cave Development in the limestone of the Ingleborough District. Geographical Journal, Vol.136, 574-585.

Waltham, A C, 1971. Shale units in the Great Scar Limestone of the southern Askrigg Block. 
Proceedings of the Yorkshire Geological Society, Vol.38, 285-292.

Waltham, A C, 1974.Speleogenesis of the Caves of Leck Fell. 273-309 in Limestones and Caves of North-West England. Waltham, A C (editor). (Newton Abbot: David and Charles.)

Warwick, G T, 1953. The origin of limestone caverns. 41-61 in British Caving. Cullingford, C H D (editor). (London: Routledge and Kegan Paul.)

White, W B, 1988. Geomorphology and Hydrology of Karst Terrains. (Oxford: Oxford University Press.)

Worthington, S R H, 1991. Karst hydrogeology of the Canadian Rocky Mountains. Unpublished $\mathrm{PhD}$ Thesis, McMaster University.

\section{ZAKAJ IN KAKO SO KRAŠKE VOTLINE “ORGANIZIRANE”: ALI PRETEKLOST NUDI KJUČ K SEDANJOSTI?}

\section{Povzetek}

\section{KRATEK POGLED V ZGODOVINO}

Premnogi raziskovalci krasa in jam omenjajo, da kraške votline (jame) v kamnini niso razmetane poljubno, ampak se v prerezu skozi kamninsko gmoto zbirajo v po vertikali jasno opredeljene kopice. Kot sledi iz objav A. Mihevca (1998) in F. Šušteršiča (1998), odražajo to urejenost enako brezstrope jame, kot danes aktivni oz. šele pred kratkim opusteli jamski spleti. Nekateri avtorji so to "zbiranje" tolmačili kot odsev nekdanje oblikovanosti kraškega površja, namreč "erozijskih površin" ali "erozijskih nivojev". Drugim te povezave niso bile tako samoumevne in so se raje sklicevali na "geološko kontrolo", ali natančneje, "geološki predris". Geološko zasnovanost je lahko sprejeti, kadar govorimo o bolj ali manj vodoravnih in tektonsko nepoškodovanih skladih; manj uspešni sta bila interpretacija in odkrivanje logičnih zvez v tektonsko poškodovanih in nagubanih zakraselih gmotah.

W. White $(1988,85)$, je zapisal: “...eno izmed vprašanj, na katera morajo odgovoriti modeli o nastanku jam je, zakaj se kraške votline včasih zbirajo v "nadstropja”..." Besedica "včasih" je pomembna, kajti "nadstropja" se ne pojavljajo povsod, v vseh kamninskih sekvencah in vseh strukturnih kombinacijah. Pravzaprav bi smeli "nadstropja" pričakovati kot samoumevna edino tam, kjer so se pojavljali erozijski nivoji (nekraški pojavi) in nanje vezane gladine podtalnice, ki bi lahko bili glavni faktor pri razvoju "nadstropij".

Do danes se je pojavilo mnogo teorij o nastanku jam. Za nekatere se zdi, da so ponudile vsaj krajevno uspešne razlage za nastanek jamskih "nadstropij”. V svojem razmišljanu o članku M. Sweetingove (1950) je angleški geomorfolog G. Warwick zapisal: "Sweetingova je pokazala, da se nekatere izmed velikih jamskih dvoran v severozahodnem Yorkshiru pojavljajo na jasno opredeljivih višinah, ki so verjetno povezane s postopnim poglabljanjem površinskih dolin". Jamskih "nadstropij" so se seveda zavedali že pred letom 1950. V njihov nastanek in pomen so se poglabljali mnogi avtorji. Ni naš namen, da bi podrobno obnavljali vso zgodovino - v nadanjem omenimo le nekatere najbistvenejše misli.

L. Sawicki (1909) je navajal "razvojne nivoje", ki naj bi se nanašali na zaporedne gladine 
piezometra. Posamezne njegove misli se skladajo z nekaterimi mlajšimi teorjami o razvoju jam. A. Droppa (1957) je razvoj Demänovskih jam na Slovaškem opisal s pomočjo številnih, jasno izraženih "nadstropij". Ta imajo tudi sorazmerno stalno višino - odraz nekdanjih višin rečnih tokov. A. Bögli (1966) je opisoval jamske nivoje v Höllochu in jih primerjal z vrezovanjem doline reke Muota.

S pomočjo matematične analize rezultatov hidrokemičnih opazovanj je S. Worthington (1991) pokazal, da novi svežnji kanalov, vezani na posamezna "nadstropja", nastajajo znotraj prežete cone pod danes aktivnim svežnjem. Zamisel se v nekaterih pogledih sklada s Hipotezo o začetnih horizontih, ki jo je 1992 predložil D. Lowe. O urejenosti kraških votlin znotraj posameznega svežnja v Laškem Ravniku je pred kratkim razpravljal F. Šušteršič (1998). Zamisel o druženju kraških kanalov je tedaj daleč od tega, da bi bila nova.

\section{VZORČNI PRIMERI IZ YORKSHIRE DALES}

M. Sweetingova (1950) je menila, da je opazno zbiranje kraških kanalov v posameznih "nadstropjih" po skoraj vseh Yorkshire Dales posledica manjšega števila erozijskih nivojev, ki so jih geomorfologi odkrili na površju. Tolmačenje je sprejela večina takratnih raziskovalcev. Žal je njen model prezrl razlike v kamninah in predpostavljal, da so jame v homogeni apnenčevi gmoti nastajale $v$ bistvu poljubno in so njihovo nadmorsko višino odrejali le površinski faktorji.

A. Waltham (1970) je proučil mnogo jam. Naslonil se je na najsodobnejše, mnogo natančnejše meritve jam in primerjal višine posameznih geoloških teles z višinami jamskih rovov. Ugotovil je, da so bili nekateri "nivoji”, ki jih je ugotovila Sweetingova (o.c.) dejansko geološke ploskve, ki so nastale zaradi endogenih, ne erozijskih faktorjev (Sl. 2). Znotraj apnenčeve skladovnice je Waltham identificiral "cone" z mnogo "glinastih plasti" (A. Waltham 1970; 1971). Slika 3 kaže, da se "višine razvoja jam", ki jih je predložila Sweetingova in te cone skladajo le kdaj pa kdaj. Cone "glinastih plasti” in jam so v različnih krajih različno visoko.

Waltham je zaključil, da "glinene plasti" odrejajo ravoj jam kot ekrani, ki preprečujejo vodi pot drugam. Ugotovil je tudi manjše razmike "glinastih plasti" ob prelomih ter krajevna vodozbirna območja kot plosledice rahlih sinklinal. Podobne "nivoje" so našli tudi v Easegill Caverns (Ashmead, 1974), Leck Fellu (A. Waltham 1974b), Kingsdalu (D. Brook, 1974) in Gaping Gillu (R. Glover, 1974). Večina se zdi navezana na plasti glinovcev oz. druge akviklude. Ostaja pa nepojasnjeno, zakaj se najpomebnejši svežnji pojavljajo v ravno vsaki od Walthamovih z glinenimi plastmi obogatenih con.

Tabela 1 kaže povprečne nadmorske višine za razvoj jam najpomembnejših "nivojev" v naštetih kraških ozemljih. Višine na območjih 1 do 3 se spreminjajo v širokem obsegu, malo pa se spreminja debelina skladov med njimi. Sorazmerno stalne razdalje med jamskimi "nivoji" se ne da spregledati.

Slika 2a kaže tradicionalen pogled na razvoj jam, tako da se prenikla padavinska voda pretaka skozi homogeno kamninsko gmoto na pol poljubno. Na začetku ni nikakršne organizacije kanalov ali njihovih zasnov. Potem pa, ko nastane površinska dolina (Sl. 2b), se razvoj kanalov usredini na posamezne točke v dnu doline, kjer je krajevna erozijska baza. Deli na pol slučajnega spleta kanalov so dobili poudarjeno smer, v katero se razvijajo in se tako organizirajo. Ker je tektonsko popolnoma nepoškodovana apnenčeva gmota $\mathrm{v}$ začetku celo manj porozna od npr. granita, je nakazana razvojna pot morda zgrešena že v osnovi.

Slika 3a kaže alternativen pogled. Podzemski odtok je organiziran že pred vrezovanjem in se 
ozira le na plastovitost in vpad majhnega števila priviligiranih lezik, "začetnih horizontov". Ko se dolina zareže v apnence (Sl. 3b), najprej načne najvišji začetni horizont in izvir se pojavi na tisti strani doline, ki je nasprotni vpadu. V času, ko izvir deluje, se kanali polagoma orientirajo proti njemu, vendar pa nižji začetni horizont še vedno deluje in prevaja vodo pod dolino. Ko se vrezovanje nadaljuje, prej ali slej načne nižji začetni horizont in višji izvir ostane pretežno suh. Starejši kanali, nastali ob lezikah, so še vedno tam. Lahko delujejo kot ponori, lahko jih zadelajo sedimenti, lahko zbirajo preniklo vodo nad seboj in - pač glede na nizvodne pretočne pogoje - delujejo lahko tudi kot estavele. Razmere na slikah 2 in 3 so zelo poenostavljene, vsekakor pa ilustrirajo vlogo priviligiranih lezik ("začetnih horizontov"). Med možnostmi, predloženimi v Hipotezi o začetnih horizontih (D. Lowe, 1992), je to pravzaprav najpreprostejši primer stratigrafskega predrisa za razvoj jamskih kanalov.

S. Worthington (1991) je pokazal, da se znotraj enega samega vodozbirnega območja odtok odvija na več različnih ravneh (Sl. 4). 99\% kalcijevega karbonata se raztopi v epikraški coni in le $1 \%$ v zgornjem delu endokrasa. V spodnjem delu slednjega poteka sulfatna reakcija. Ker se zniževanje površja nikoli ne ustavi, se naštete cone pomikajo navzdol in v nekdanji coni sulfatne reakcije prevlada hidrokarbonatna. To je bilo ugotovljeno v porečju reke Big Horn v Wyomingu, USA (S. Egemeier, 1981; W. Sando, 1988). Worthington ni iskal nadaljnjih povezav s stratigrafijo, toda logične zveze s hipotezo o začetnih horizontih so nespregledljive.

Lowe (1992) je ugotovil da so trije "nivoji" razvoja jam (1 - 3, Tabela 1) dejansko posamezni stratigrafski horizonti, ki ležijo znotraj ali na mejah asbijske stopnje (Tabela 2). Vrh asbija (glavni cikel št. 5) označujejo kopenski sedimenti, ki krajevno vključujejo pole premoga in mudstona. Njegova baza leži na regresijskih kamninah (skupaj z mikriti - "porcelanske plasti”) s katerimi se je končala sedimentacija v spodnji, holkerijski stopnji. Ta plast je razpoznavna prek zahodnih Dales in njena navzočnost olajšuje korelacijo "nivojev" v Gaping Gillu z votlinami bolj na zahodu. Srednji asbij označuje menjavanje zelo razgibanih paleokraških površin z do $2 \mathrm{~m}$ debelo plastjo glinovca, psevdobrečami in krajevnimi obogatitvami s školjčnimi lumakelalmi. Vse to nakazuje vrzel med dvema (v tem primeru podrejenima) sedimentacijskima cikloma. Ti horizonti so izjeme med več kot 50 lezikami znotraj desetih asbijskih podciklov in izkazujejo lastnosti začetnih horizontov. Različne razlage za dogajanje v začetnih horizontih so pretresli D. Lowe (1992) in D. Lowe in J. Gunn (1997), toda osnovni vzrok za začetje mora biti še bolj fundamentalen.

Večina razvoja jam v Western Dales se je odvila vzdolž treh začetnih horizontov. Razpoke in prelomne strukture so vodile edino razvoj jaškov ali hidroloških zvez med začetnimi horizonti oz. med elementi znotraj istega začetnega horizonta, ki jih je bil razmaknil prelom. Oba glavna izvira (Leck Beck Head in Keld Head) ležita na spodnjem horizontu (porcelanske plasti). Rahlo toneče sinklinale so usmerjale glavne odtoke vzdolž začetnih horizontov. Pritoki sledijo vpadu proti osem sinklinal, vmesne antiklinale pa so nekakšne razvodnice med posameznimi jamskimi sistemi. Na površju se antiklinale kažejo kot doline z mnogimi ponori ali pa kot nizi kraških globeli, ki jim krajevno prebivalstvo pravi "shakeholes".

Model, ki vključuje iste tri začetne hotrizonte, lahko pojasni tudi bolj zapleten odtok in odnose med povezanimi vzpenjajočimi se izviri zahodnega in vzhodnega Ribblesdala. Izgleda, da so pred pleistocenskimi poledenitvami neizdelani kraški odtoki sledili splošnemu vpadu skladov, kar je sovpadalo regionalnemu hidravličnemu gradientu od zahoda proti vzhodu. Drugi, manj izraženi začetni horizonti so imeli podobne učinke tik nad bazo apnenčeve skladovnice. Kot kaže slika 3 so 
morda obstojale zasnove hidravličnih dvigov, ki so se nanašale na najvišji horizont na zahodu protoRibblesdala. V času pleistocena so ledeniki vsesplošno znižali površje in tudi poglobili Ribblesdale ter manjšo dolino na zahodu (Crummack Dale).

Nekateri spleti votlin, vezani na zgornji asbijski horizont, so bili v bližini doline Ribble odrezani in so pustili za seboj jame, ki danes "visijo" v pobočjih doline. Nekatere od teh jam so danes iztokih najvišjih voda.

Zasnove kanalov v "šibkih" začetnih horizontih so bile prerezane in nastali so današnji izviri tik bazalne diskordance pri Austwick Beck Head v Crummackdale ter pri Brants Gill, Douk Ghyll in Dub Cote v Ribblesdale (S1. 10).

Večina globokih odtokov iz Penyghenta in Fountains Fella zateka danes v jamske sisteme, ki uporabljajo tri glavne začetne horizonte. Tok po vpadu navzgor je učinkovitejši kot tok navzdol. Odtok z južnega Simon Fella ima podobne odnose z Austwick Beck Headom, vendar teče voda tokrat po vpadu navzdol.

Bolj proti severu so apnenci ob prelomih pogreznjeni in kraške vodne poti izpred pleistocena prečkajo apnečevo ozemlje, tokrat pod Ribblom. Odtok z območja Sell Gilla se hidravlično dvigne skozi okno v globljih spletih, ki so nastali še pred poledenitvami in ki na bazi asbija ali vzdolž še nižjih, "šibkih" začetnih horizontov verjetno prevajajo vodo reginalno v smeri zahod-vzhod.

Odtok s Simon Fella na severu sledi drugi predpoledenitveni smeri, verjetno (̌̌e ne dokončno potrjeno) po istih začetnih horizontih vendar v bloku, ki ga od ostalega apnenčevega ozemlja delijo prelomi.

Opuščene vodne poti izpred poledenitev so med južnim Simon Fellom in Ribblesdalom ohranjene vsaj v bazalni začetni coni v asbiju. Možno je, da se poplavne vode s tega ozemlja poslužujejo starih poti, potem ko so napolnile zaledje maksimiranega novega odtoka pri Austwick Beck Headu.

Verjetno je bil prvotni hidravlični gradient usmerjen od zahoda proti vzhodu in se je nadaljeval prek predpoledenitvenega Crummack Dala in proto-Ribblesdala. Zatorej je današnji vodni tok s Fountains Fella proti severozahodu zasukan glede na regionalni trend. Na to jasno kažejo hitrosti odtoka s Fountains Fella, ki so za velikostni red manjše od onih z območja Penyghenta.

\section{ZAČETNI HORIZONTI IN BREZSTROPE JAME}

Jame niso najboljši kraji, kjer bi opazovali začetne horizonte. Erozija in preperevanje uničijo ključne strukture, še posebej tam, kjer vadozna voda zareže korita globoko pod vodilne horizonte. Najbolje razvidimo obstoj in obseg horizontov, kjer bi se lahko razvile jame - pa tudi razlike z ostalimi, manj primernimi lezikami - v svežih odkopih, kamnolomih in cestnih usekih.

Sliki 6 in 7 kažeta subhorizontalne plasti zelo čistega dinantskega apnenca v Derbyshire Peak Districtu. Na sliki 6 sta drugo nad drugim dve čeli kamnoloma, ki skupaj zavzemata več kot $60 \mathrm{~m}$ apnečevih plasti. Videti je mnogo lezik (medsebojna razdalja je 1 do $2 \mathrm{~m}$ ), a le dve, po ena v vsakem čelu, padeta v oči. Slika 7 kaže spodnje čelo in njegovo pomembno leziko. Ves horizont je na drobno preluknjan s širokimi votlinami, nastalimi z raztapljanjem. To potrjuje, da začetna aktivnost prizadene bolj ali manj ves primeren horizont in se tokovi usredinijo v strukturna znižanja šele po tektonskem dvigu. Kamnina pod leziko kaže madeže železovih oksidov, verjetno sproščenih pri oksidaciji sulfidnih mineralov odloženih med obe plasti. Pri razpadu sulfidov se sprošča žveplena kislina, ki je učinkovit dejavnik raztapljanja in je gonilo vsaj enega tipa začetja. 
Dinantska skladovnica v Forest of Dean vsebuje med številnimi jasno opaznimi lezikami podobno omejeno število začetnih horizontov. Zakrasevanju bolj prikladne lezike se kažejo v jamah in železnih orudenenjih (D. Lowe, 1993). Železova ruda se je odložila v jame še v triasu in rudna telesa so se pojavila na površju šele, ko ga je denudacija primerno znižala. Slika 5 kaže odnose med rudnimi telesi in stratigrafijo. Stari dnevni kopi odražajo sistem nekdanjih jam, ki so danes ostale brez stropov. $\mathrm{V}$ predelih, ki jih ni prizadelo rudarjenje, se pojavljajo brezstrope jame, primerljive tem v Sloveniji.

\section{NEKAJ POUDARKOV}

Identični stratigrafski horizonti so nosilici razvoja jam v različnih višinah na večje razdalje. Tega ni mogoče pričakovati, razen če zgodnji razvoj jam ni starejši kot današnja oblikovanost površja oz. erozijska baza. Odseki teh horizontov vklapljajo jamske segmente celo v strmo naklonjenih plasteh in nagubanih kamninah. To je razložljivo le, če so nudili razvoju vodnih poti (raztapljanju kamnine) posebne ugodnosti še preden je obstajala današnja gladina podtalnice. Nobena plast kamnine ni popolnoma homogena, četudi jo opisujemo kot "masivno". Vsaka plast je zapis zaporedja različnih, a med seboj vzročno povezanih dogodkov. Razlike med plastmi, ali celo znotraj posamezne plasti, so krajevnega ali celo regionalnega pomena. Začetni horizonti (ali priviligirane plasti) predstavljajo le mnjšino (1 do 2\%) znotraj celote in odražajo bistveno boljše pogoje za nastanek jamskih kanalov kot mnogo številnejši sosedje. Zatorej ni nujno, da bi faktor, ki napravi neko plast ugodnejšo, učinkoval enako tudi v drugačni sekvenci.

Če se, kot pravi S. Worthington (1991), raztapljanje odvija v več nivojih istočasno, lahko najvišji nivoji ostanejo nespremenjeni, ko se zaradi dviga odtok prestavi relativno navzdol. Elementi, ki odrejajo, vršijo in pospešujejo najzgodnejši razvoj kanalov, morajo tedaj biti tam že pred tektonskim dvigom.

Hipoteza o začetnih horizontih (D. Lowe, 1992) zaključuje, da se začetne ošibitve v karbonatni skladovnici, ki imajo dimenzije sedimentacjskega bazena in neposredno odražajo stratigrafske odnose, v karbonatno sekvenco vtisnejo še med ali kmalu po diagenezi, zagotovo pa pred tektoniko. Ti usmerjajo kasnejšo rast jamskih kanalov znotraj strukturno odrejenih con, ki se ravnajo po hidravličnem gradientu. France Šušteršič (1995) in sodelavci so na Krnu odkrili jasne poznodiagenetske strukture, ki govorijo v prid gornji hipotezi.

\section{ZAKLJUČKI}

Naj bo v subhorizontalnih ali nagubanih kamninah, organizacija jamskega spleta je v osnovi vezana na stratigrafijo. V mnogih primerih priviligirana lezika odgovarja meji sedimenatcijskega cikla. Začetje razvoja kanalov vzdolž priviligiranih lezik se prične med diagenezo in je zatorej predtektonski proces. Ob pomoči primernih geoloških podatkov nam poznavanje naštetih odnosov omogoča, da na osnovi poznavanja preteklih geoloških dodgodkov napovemo današnje razpostave jam. 